\title{
Front Matter: Volume 7926
}

, "Front Matter: Volume 7926," Proc. SPIE 7926, Micromachining and Microfabrication Process Technology XVI, 792601 (28 March 2011); doi: $10.1117 / 12.891322$

SPIE. Event: SPIE MOEMS-MEMS, 2011, San Francisco, California, United States 


\title{
PROCEEDINGS OF SPIE
}

\section{Micromachining and Microfabrication Process Technology XVI}

\author{
Mary Ann Maher \\ Jung-Chih Chiao \\ Paul J. Resnick \\ Editors
}

25 and 27 January 2011

San Francisco, California, United States

Sponsored and Published by

SPIE 
The papers included in this volume were part of the technical conference cited on the cover and title page. Papers were selected and subject to review by the editors and conference program committee. Some conference presentations may not be available for publication. The papers published in these proceedings reflect the work and thoughts of the authors and are published herein as submitted. The publisher is not responsible for the validity of the information or for any outcomes resulting from reliance thereon.

Please use the following format to cite material from this book:

Author(s), "Title of Paper," in Micromachining and Microfabrication Process Technology XVI, edited by Mary Ann Maher, Jung-Chih Chiao, Paul J. Resnick, Proceedings of SPIE Vol. 7926 (SPIE, Bellingham, WA, 2011) Article CID Number.

ISSN 0277-786X

ISBN 9780819484635

Published by

SPIE

P.O. Box 10, Bellingham, Washington $98227-0010$ USA

Telephone +1 3606763290 (Pacific Time) · Fax +1 3606471445

SPIE.org

Copyright (C) 2011, Society of Photo-Optical Instrumentation Engineers

Copying of material in this book for internal or personal use, or for the internal or personal use of specific clients, beyond the fair use provisions granted by the U.S. Copyright Law is authorized by SPIE subject to payment of copying fees. The Transactional Reporting Service base fee for this volume is $\$ 18.00$ per article (or portion thereof), which should be paid directly to the Copyright Clearance Center (CCC), 222 Rosewood Drive, Danvers, MA 01923. Payment may also be made electronically through CCC Online at copyright.com. Other copying for republication, resale, advertising or promotion, or any form of systematic or multiple reproduction of any material in this book is prohibited except with permission in writing from the publisher. The CCC fee code is 0277-786X/11/ \$18.00.

Printed in the United States of America.

Publication of record for individual papers is online in the SPIE Digital Library.

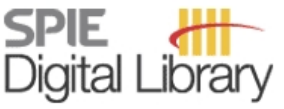

SPIEDigitalLibrary.org

Paper Numbering: Proceedings of SPIE follow an e-First publication model, with papers published first online and then in print and on CD-ROM. Papers are published as they are submitted and meet publication criteria. A unique, consistent, permanent citation identifier (CID) number is assigned to each article at the time of the first publication. Utilization of CIDs allows articles to be fully citable as soon as they are published online, and connects the same identifier to all online, print, and electronic versions of the publication. SPIE uses a six-digit CID article numbering system in which:

- The first four digits correspond to the SPIE volume number.

- The last two digits indicate publication order within the volume using a Base 36 numbering system employing both numerals and letters. These two-number sets start with 00, 01, 02, 03, 04 , 05, 06, 07, 08, 09, OA, OB ... 0Z, followed by 10-1Z, 20-2Z, etc.

The CID number appears on each page of the manuscript. The complete citation is used on the first page, and an abbreviated version on subsequent pages. Numbers in the index correspond to the last two digits of the six-digit CID number. 


\section{Contents}

vii Conference Committee

ix Lateral spread of MEMS WDM technologies (Plenary Paper) [7930-202]

H. Toshiyoshi, The Univ. of Tokyo (Japan)

xxi Toy Story: what I have learned from playing with toys about the physics of living cells (Plenary Paper) [7929-203]

R. H. Austin, Princeton Univ. (United States)

\section{SESSION 1 OPTICAL DEVICE FABRICATION}

792602 IR photodetector based on an optically cooled micromirror as a light pressure sensor [7926-01]

G. P. Berman, A. R. Bishop, B. M. Chernobrod, Los Alamos National Lab. (United States);

U. Mohideen, Univ. of California, Riverside (United States)

792603 Endurance analysis of optical master stamps for UV-replication [7926-02]

F. C. Wippermann, A. Reimann, G. Leibeling, Fraunhofer Institute for Applied Optics and Precision Engineering (Germany)

792604 Thermo-optic coefficients of SiC, GaN, and AIN up to $512^{\circ} \mathrm{C}$ from infrared to ultraviolet region for tunable filter applications [7926-03]

N. Watanabe, T. Kimoto, J. Suda, Kyoto Univ. (Japan)

\section{SESSION 2 LASER-BASED PROCESSING}

792606 Laser processing inside transparent materials: dependence on pulse length and wavelength [7926-05]

U. Loeschner, J. Schille, R. Ebert, H. Exner, Hochschule Mittweida - Univ. of Applied Sciences (Germany)

792607 Sub-micron texturing of silicon wafer with fiber laser [7926-06]

H. Farrokhi, W. Zhou, Nanyang Technological Univ. (Singapore); H. Y. Zheng, Z. Li, Singapore Institute of Manufacturing Technology (Singapore) 
792609 First results on electrostatic polymer actuators based on UV replication [7926-08]

N. Lange, Friedrich Schiller Univ. of Jena (Germany) and Fraunhofer Institute for Applied Optics and Precision Engineering (Germany); F. Wippermann, R. Leitel, Fraunhofer Institute for Applied Optics and Precision Engineering (Germany); C. Bruchmann, Friedrich Schiller Univ. of Jena (Germany) and Fraunhofer Institute for Applied Optics and Precision Engineering (Germany); E. Beckert, R. Eberhardt, Fraunhofer Institute for Applied Optics and Precision Engineering (Germany); A. Tünnermann, Friedrich Schiller Univ. of Jena (Germany) and Fraunhofer Institute for Applied Optics and Precision Engineering (Germany)

7926 OA Commercial plexiglass mirrors and MEMS: new approach toward low cost polymer microsystems [7926-09]

A. Khosla, B. L. Gray, Simon Fraser Univ. (Canada)

7926 OB Fabrication of electrostatic-actuated single-crystalline $4 \mathrm{H}-\mathrm{SiC}$ bridge structures by photoelectrochemical etching [7926-11]

N. Watanabe, T. Kimoto, J. Suda, Kyoto Univ. (Japan)

7926 OC Poly-HDDA microstructure fabrication using microstereolithography for microcantileverbased sensor technology [7926-22]

A. Goswami, A. Phani, Indian Institute of Science Bangalore (India); A. Krisna,

N. Balashanmugam, Central Manufacturing Technology Institute (India); G. Madras,

A. M. Umarji, Indian Institute of Science Bangalore (India)

\section{SESSION 4 MATERIALS, METROLOGY, AND COMPUTER-AIDED DESIGN}

7926 OD MEMS product engineering: methodology and tools [7926-12]

D. Ortloff, J. Popp, Process Relations GmbH (Germany); T. Schmidt, K. Hahn, M. Mielke,

R. Brück, Univ. of Siegen (Germany)

7926 OE Automated measurement of centering errors and relative surface distances for the optimized assembly of micro-optics [7926-13]

P. Langehanenberg, E. Dumitrescu, J. Heinisch, S. Krey, A. K. Ruprecht, TRIOPTICS GmbH (Germany)

7926 OF Impact of using filtration on global and local uniformity of spin on glue materials [7926-14] S. Bernard, Entegris GmbH (Germany); R. A. Miller, IMEC (Belgium); V. Pepper, Nanda Technologies GmbH (Germany); J. Braggin, Entegris, Inc. (United States); F. F. C. Duval, IMEC (Belgium)

\section{POSTER SESSION}

7926 Ol Design and fabrication of a CMOS MEMS logic gate [7926-18]

C.-Y. Tsai, T.-L. Chen, National Chiao Tung Univ. (Taiwan); H.-H. Liao, C.-F. Lin, Y.-Z. Juang, National Chip Implementation Ctr. (Taiwan) 
7926 0J Development of a novel thermal switch through CMOS MEMS fabrication process [7926-19] Y.-L. Lai, National Chip Implementation Ctr. (Taiwan); L.-C. Chou, National Chiao Tung Univ. (Taiwan); Y.-Z. Juang, H.-H. Tsai, National Chip Implementation Ctr. (Taiwan); S.-C. Huang, J.-C. Chiou, National Chiao Tung Univ. (Taiwan)

$7926 \mathrm{OL}$ Large scale micropatterning of multi-walled carbon nanotube/polydimethylsiloxane nanocomposite polymer on highly flexible $12 \times 24$ inch substrates [7926-21]

A. Khosla, D. Hilbich, C. Drewbrook, D. Chung, B. L. Gray, Simon Fraser Univ. (Canada)

Author Index 
Downloaded From: https://www.spiedigitallibrary.org/conference-proceedings-of-spie on 26 Apr 2023

Terms of Use: https://www.spiedigitallibrary.org/terms-of-use 


\title{
Conference Committee
}

\author{
Symposium Chair \\ Thomas J. Suleski, The University of North Carolina at Charlotte (United \\ States) \\ Symposium Cochair
}

Harald Schenk, Fraunhofer Institute for Photonic Microsystems

(Germany)

Conference Chairs

Mary Ann Maher, SoftMEMS (United States)

Jung-Chih Chiao, The University of Texas at Arlington (United States)

Paul J. Resnick, Sandia National Laboratories (United States)

Program Committee

Mu Chiao, The University of British Columbia (Canada)

Debabani Choudhury, HRL Laboratories, LLC (United States)

Sanjay Krishna, The University of New Mexico (United States)

Tamal Mukherjee, Carnegie Mellon University (United States)

Metin Ozen, Ozen Engineering, Inc. (United States)

Yu-Chuan Su, National Tsing Hua University (Taiwan)

T. C. Yih, Oakland University (United States)

Session Chairs

1 Optical Device Fabrication

Mary Ann Maher, SoftMEMS (United States)

2 Laser-based Processing

Mary Ann Maher, SoftMEMS (United States)

3 MEMS Device Fabrication

Paul J. Resnick, Sandia National Laboratories (United States)

4 Materials, Metrology, and Computer-Aided Design

Paul J. Resnick, Sandia National Laboratories (United States) 
Downloaded From: https://www.spiedigitallibrary.org/conference-proceedings-of-spie on 26 Apr 2023

Terms of Use: https://www.spiedigitallibrary.org/terms-of-use 